\title{
Photoassisted Electrodeposition of a Copper(I) Oxide Film
}

\author{
Seunghun Kim, Yongkuk Kim, Jaegoo Jung and Won-Seok Chae* \\ School of Life-Chemistry, Daejin University, Pocheon, 487-711 Gyeonggi, Republic of Korea
}

\begin{abstract}
Photoassisted electrodeposition of a cuprous oxide $\left(\mathrm{Cu}_{2} \mathrm{O}\right)$ thin film was studied to find the optimum conditions lowering the deposition temperature. $\mathrm{Cu}_{2} \mathrm{O}$ films were electrochemically deposited on FTO by cycling the electrode potential between $0.0 \mathrm{~V}$ and $-0.8 \mathrm{~V}(\mathrm{Ag} \mid \mathrm{AgCl})$, in an aqueous solution. A simple deposition cell was designed to allow simultaneous thermostating and polychromic illumination. Under illumination, the $\mathrm{Cu}_{2} \mathrm{O}$ film deposition occurred, even at a temperature lower than the temperature observed under dark conditions. X-ray diffraction (XRD) analysis confirmed that these films were indexed as cubic symmetric structured pure $\mathrm{Cu}_{2} \mathrm{O}$ (JCPDS: 05-0667), and UV-visible absorption spectra show an optical band-gap energy of $2.5 \mathrm{eV}$. [doi:10.2320/matertrans.M2014391]
\end{abstract}

(Received November 5, 2014; Accepted December 4, 2014; Published January 17, 2015)

Keywords: copper(I) oxide, thin-film, photoassisted electrodeposition, electrochemical deposition, cyclic voltammetry

\section{Introduction}

Electrodeposition (electrochemical deposition) of cuprous oxide $\left(\mathrm{Cu}_{2} \mathrm{O}\right)$ has been widely studied for a rechargeable battery electrode, ${ }^{1,2)}$ a catalyst, ${ }^{3-7)}$ a sensor, ${ }^{8,9)}$ and as a sensitizer for solar cells. ${ }^{10-13)}$ The compound is especially attractive in photovoltaic devices because of its suitable band-gap energy. Additionally, its abundance and nontoxicity make $\mathrm{Cu}_{2} \mathrm{O}$ an excellent candidate for large scale utilization in photovoltaic devices. Electrodeposition ${ }^{14)}$ has many advantages such as low cost, simple processes, and controllable thickness and structure of the films. Many studies have reported nanostructured $\mathrm{Cu}_{2} \mathrm{O}$ deposition, ${ }^{2,15,16)}$ particle shape, ${ }^{3,11,12,17)}$ deposition temperature, ${ }^{18,19)}$ and film orientation control ${ }^{20}$ ) using electrodeposition methods. The electrodeposition of the $\mathrm{Cu}_{2} \mathrm{O}$ film was usually achieved at temperatures ${ }^{5,10,20-23)}$ higher than room temperature to overcome the activation energy. We employed a photoassisted electrodeposition system, using a high-powered Xe-lamp as another energy source, which is expected to accelerate the rate of electrodeposition. Photoirradiation of the electrodeposition process ${ }^{13,24,25)}$ has additional advantages, such as the capability to grow both thin and thick high-quality films, with higher growth rate and less negative deposition potential. The photoassisted chemical deposition of $\mathrm{p}$ $\mathrm{Cu}_{2} \mathrm{O} / \mathrm{n}-\mathrm{ZnO}$ was reported for the construction of a heterostructure on a quartz glass. ${ }^{26)}$

In this paper, we described a simple deposition cell, which was controlled by a thermostat and subjected to photoirradiation at the same time. The deposition cell was constructed with a glass body, with the top and bottom sealed using Teflon ${ }^{\circledR}$ plates. At the bottom a transparent glass electrode, such as fluorine doped tin oxide (FTO), was fitted. Therefore, light could pass from the back side to the front active side of the FTO. We carried out the photoassisted electrodeposition of a $\mathrm{Cu}_{2} \mathrm{O}$ film and determined the effect of the presence or absence of a polychromic light source on the electrodeposited $\mathrm{Cu}_{2} \mathrm{O}$ films.

\section{Experimental Procedure}

Photoassisted electrodeposition of $\mathrm{Cu}_{2} \mathrm{O}$ was carried

*Corresponding author, E-mail: wschae@daejin.ac.kr out by cyclic voltammetry (CV), in an aqueous solution containing $0.10 \mathrm{~mol} \cdot \mathrm{L}^{-1} \mathrm{CuSO}_{4} \cdot 5 \mathrm{H}_{2} \mathrm{O}(99.0 \%$ Kanto Chemicals, Japan) and $1 \mathrm{~mol} \cdot \mathrm{L}^{-1}$ lactic acid (99\% Kanto Chemicals, Japan). The $\mathrm{pH}$ of the solutions was adjusted to 12.7 with a concentrated $\mathrm{NaOH}$ solution (Dae-Jung Chemicals, Korea). A transparent conducting glass (fluorine doped tin oxide; FTO, TEC 8, Pilkington, USA) and a Pt mesh (99.99\%, Sigma-Aldrich, USA) were used as the working electrode (deposition substrate) and the counter electrode, respectively. A reference electrode, $\mathrm{Ag} \mid \mathrm{AgCl}$ (saturated $\mathrm{KCl}$ ) was encased in a bridge tube, connected to the solution by a Vycor tip. All the potentials were measured against this reference electrode. For the $\mathrm{CV}$, the potential scan was started at $0 \mathrm{~V}(\mathrm{Ag} \mid \mathrm{AgCl})$, reversed at $-0.8 \mathrm{~V}$, and then terminated at $0 \mathrm{~V}$, with 20 cycles of repetition, at a scan rate of $0.05 \mathrm{~V} \mathrm{~s}^{-1}$. X-ray diffraction (XRD) patterns were measured with a Rigaku X-ray diffractometer (Tokyo, Japan) using $\mathrm{Cu} \mathrm{K} \alpha$ $(40 \mathrm{kV}, 30 \mathrm{~mA})$ radiation. The $2 \theta$ range, from 20 to $70^{\circ}$, was scanned at $3^{\circ} \mathrm{min}^{-1}$. The surface images of the films was observed using a scanning electron microscope (SEM; Philips XL-30 ESEM, USA). Optical studies were performed on the films deposited on the FTO substrates using an Agilent 8453 UV-Vis spectrophotometer (Palo Alto, CA, USA).

The photoassisted electrodeposition cell is shown in Fig. 1. A cylindrical water jacketed glass tube (Fig. 1-5) and three Teflon ${ }^{\circledR}$ plates (Fig. 1-4), one positioned at the top and two at the bottom of the glass tube, were clamped together using four sets of screw bolts and nuts. The working electrode, FTO-glass (Fig. 1-6), was positioned on the lowest Teflon ${ }^{\circledR}$ plate (Fig. 1-7) through which a bundle of optical fibers was inserted. The light source, $150 \mathrm{~W}$ Xe-lamp, used for photoassistance was irradiating at a wavelength above 230 nm (LS 150 Xe, Abet Technologies, Inc., USA).

\section{Results and Discussions}

The electrodeposition of the $\mathrm{Cu}_{2} \mathrm{O}$ film was carried out using an electrode potential cycling between $0.0 \mathrm{~V}$ and $-0.8 \mathrm{~V}(\mathrm{Ag} \mid \mathrm{AgCl})$ in the lactic acid electrolyte solution (at $\mathrm{pH}$ 12.7), containing $\mathrm{CuSO}_{4} \cdot 5 \mathrm{H}_{2} \mathrm{O}$ as the precursor. As shown in Fig. 2, the well-defined cathodic peak arises from the reduction current of $\mathrm{Cu}^{2+}$ to $\mathrm{Cu}^{0}$ at $-0.6 \mathrm{~V}$ in the $1 \mathrm{st}$ cycle, and is followed by the current looping back when the direction of the potential change is reversed. This type of 

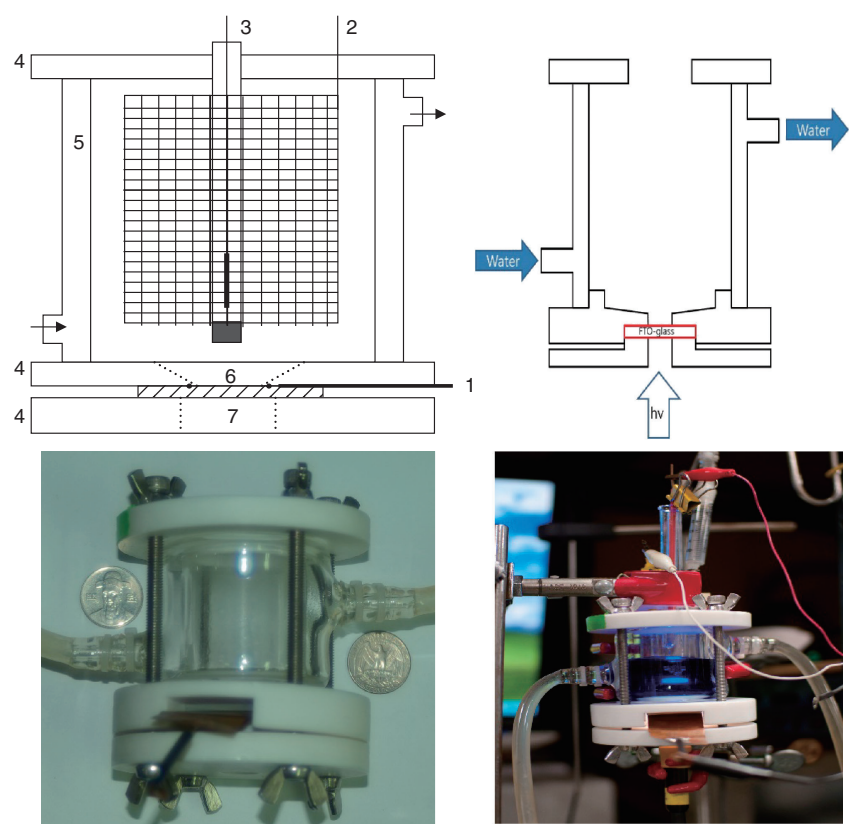

Fig. 1 Schematic diagrams and photographs of a photoassisted electrodeposition cell. 1. FTO working electrode and copper plate, for electrical contact; 2. Pt-mesh counter electrode; 3 . $\mathrm{Ag} \mid \mathrm{AgCl}$ reference electrode; 4. Teflon ${ }^{\circledR}$ plate; 5 . Water-jacketed cylindrical body; 6. Front active surface of FTO; and 7. Insertion port for the fiber optic bundle (connected to the irradiation source).

hysteresis loop is a characteristic feature of a nucleation and growth-deposition process. ${ }^{27,28)}$ The possible reaction during the cathodic reduction of $\mathrm{Cu}^{2+}$ in alkaline solution is:29)

$$
2 \mathrm{Cu}^{2+}+2 \mathrm{OH}^{-}+2 \mathrm{e}^{-} \rightarrow \mathrm{Cu}_{2} \mathrm{O}+\mathrm{H}_{2} \mathrm{O}
$$

The reduction current nearly vanished on the 2 nd cycle, and the currents gradually increased later. This dramatic decrease in current is considered to be due to the change in conductivity between a bare FTO surface and the nucleated surface. Figure 2 shows the effects of temperature and light during the $\mathrm{Cu}_{2} \mathrm{O}$ film deposition. Improvements in the film deposition were achieved by increasing the temperature, regardless of whether the experiment was conducted in darkness (Fig. 2(a)) or with illumination (Fig. 2(b)). (The improvements in the film deposition were confirmed by XRD analysis, shown in Fig. 4, as discussed below.) Under illumination, however, the $\mathrm{Cu}_{2} \mathrm{O}$ deposition was enhanced, even at room temperature.

The cathodic process (C1) and anodic process (A1) in Fig. 3 are associated with the quasi-reversible $\mathrm{Cu}_{2} \mathrm{O}$-electrocatalysis as represented by the following reactions (eq. (2)). The formation of $\mathrm{Cu}_{2} \mathrm{O}$ occurred in the $\mathrm{C} 1$-process and $\mathrm{CuO}$ is in the A1-process. The A1-process remained under the dark conditions, but the C1-process gradually disappeared under illumination and increasing temperature, shown in Fig. 2.

$$
2 \mathrm{CuO}(s)+\mathrm{H}_{2} \mathrm{O}(l)+2 \mathrm{e}^{-} \rightleftarrows \mathrm{Cu}_{2} \mathrm{O}(s)+2 \mathrm{OH}^{-}(\mathrm{aq})
$$

Under illumination, in Fig. 2(b) and Fig. 3(b), enhanced electrocatalytic processes are understood to be due to photoexcited electrons and photoinduced holes. At the lower temperature, $293 \mathrm{~K}$ and $303 \mathrm{~K}$, the cathodic electrocatalytic currents (C1) increased more under illumination. The deposition of $\mathrm{Cu}_{2} \mathrm{O}$ could be confirmed by the clear color change of the FTO surface, as shown in Fig. 2. Plain-view
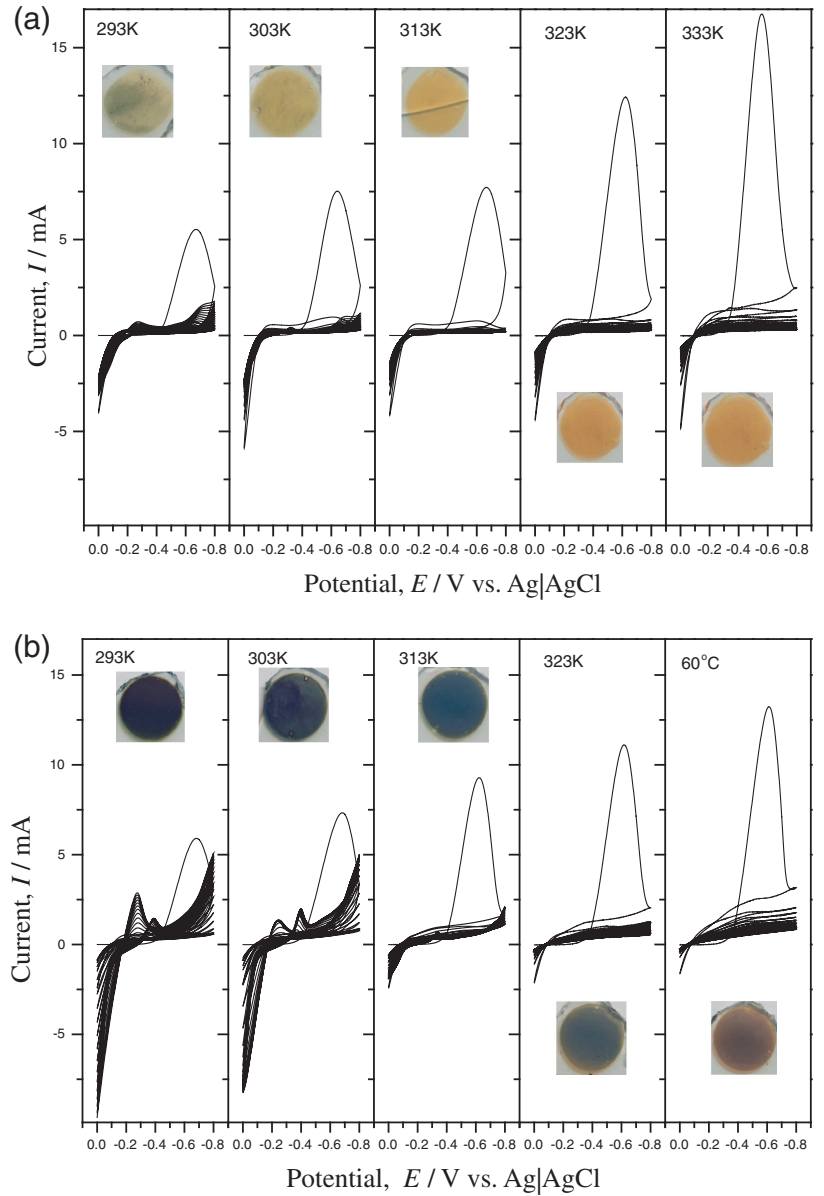

Fig. 2 Cyclic voltammograms of $\mathrm{Cu}_{2} \mathrm{O}$ film electrodeposition on FTO in aqueous $0.10 \mathrm{~mol} \cdot \mathrm{L}^{-1} \mathrm{CuSO}_{4}$ and $1 \mathrm{~mol} \cdot \mathrm{L}^{-1}$ lactic acid solution adjusted to $\mathrm{pH} 12.7$ with $\mathrm{NaOH}$, obtained in darkness (a) and with irradiation (b). Potential scan was started at $0 \mathrm{~V}(\mathrm{Ag} \mid \mathrm{AgCl})$, reversed at $-0.8 \mathrm{~V}$, and then terminated at $0 \mathrm{~V}$, with 20 cycles of repetition, at a scan rate of $0.05 \mathrm{~V} \cdot \mathrm{s}^{-1}$.

SEM images of electrodeposited films obtained at $293 \mathrm{~K}$ in Fig. 2(a) and (b) were shown in Fig. 3(a) and (b), respectively.

In Fig. 2 and Fig. 3, especially at the curved arrow in Fig. 3(b), the anodic reduction peak (near $-0.4 \mathrm{~V}$ ) featuring adsorption phenomena, is relevant to $\mathrm{C} 2$, which seems to be related to the adsorption of oxygen dissolved in the electrolyte solution; $\mathrm{O}_{2}(\mathrm{aq}) \rightarrow \mathrm{O}_{2}$ (ads) following the reduction; $\mathrm{O}_{2}$ (ads) $+\mathrm{e}^{-} \rightarrow \mathrm{O}_{2}{ }^{-}$(ads). The reduced and adsorbed oxygen ion, $\mathrm{O}_{2}{ }^{-}$(ads), is likely to be desorbed and reduced to the more stable oxygen anion, $\mathrm{O}^{2-}(\mathrm{aq})$ during the reversal of the anodic scan. ${ }^{30)}$ As the temperature was elevated, the reduction process $(\mathrm{C} 2)$ and the anodic reduction peak could not be observed because of the decrease in solubility of the dissolved oxygen, regardless of whether the experiment was conducted with or without light. More detailed studies are necessary for the anodic reduction peaks:

$$
\mathrm{C} 2: \mathrm{O}_{2} \text { (ads) }+\mathrm{e}^{-} \rightarrow \mathrm{O}_{2}{ }^{-} \text {(ads) }
$$

Anodic reduction peak: $\frac{1}{2} \mathrm{O}_{2}^{-}($ads $)+\mathrm{e}^{-} \rightarrow \mathrm{O}^{2-}(\mathrm{aq})$

The electrodeposited $\mathrm{Cu}_{2} \mathrm{O}$ films in this study are photoresponsive semiconductor materials. The desorbed oxygen anion, $\mathrm{O}^{2-}(\mathrm{aq})$, seems to have been oxidized by the photoinduced hole $\left(h^{+}{ }_{\mathrm{ph}}\right)$ in the anodic process (A1). The 

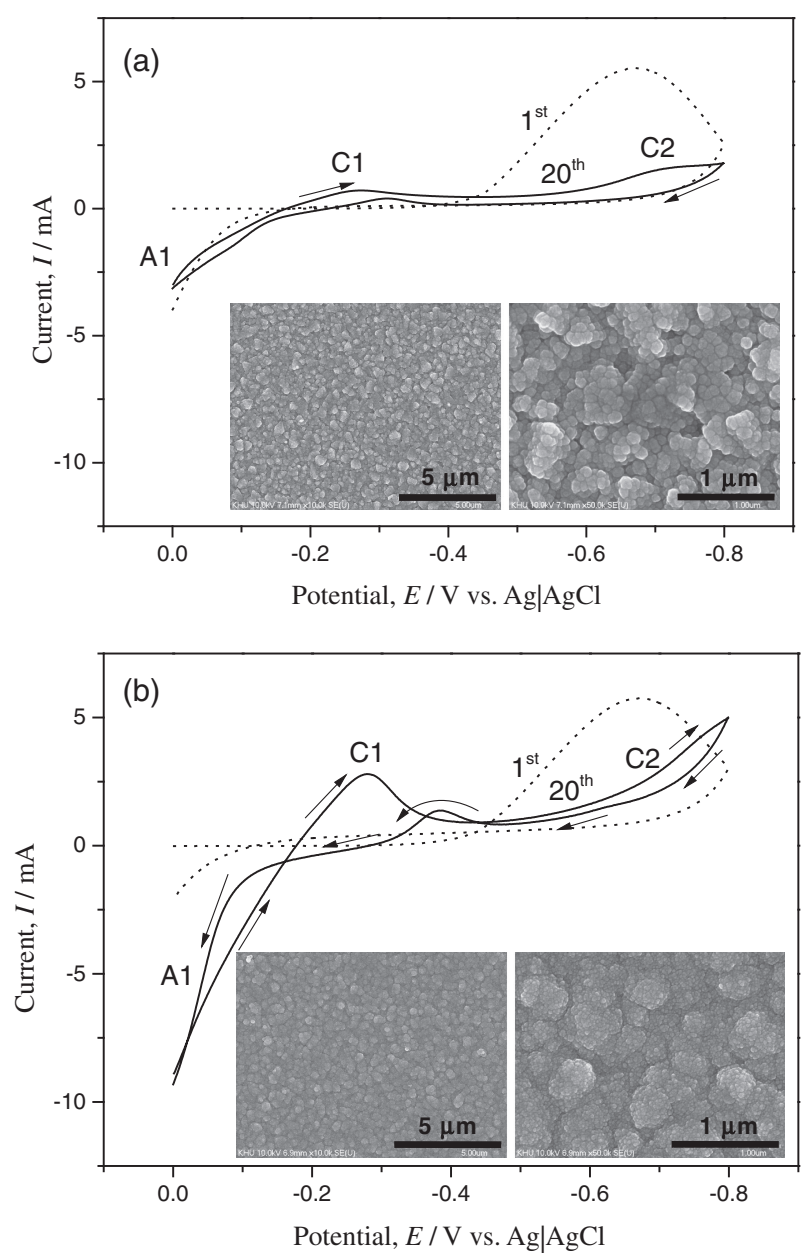

Fig. 3 Cyclic voltammograms, at $293 \mathrm{~K}$, showing the 1 st cycle (dotted line) and the 20th cycle (solid line), obtained in darkness (a) and with irradiation (b), under the same conditions as Fig. 2.

oxidized oxygen was reduced by the photoexcited electron $\left(e^{-}\right.$ph $)$in the cathodic process $(\mathrm{C} 1)$. In Fig. 2, when the dissolved oxygen concentration was high at low temperatures, these processes (A1 and $\mathrm{C} 1$ in Fig. 3) were clearly observed:

$$
\begin{aligned}
& \text { A1; photoinduced hole: } \\
& \qquad \mathrm{Cu}_{2} \mathrm{O}(s)+\mathrm{O}^{2-}(\mathrm{aq})+2 h^{+}{ }_{\mathrm{ph}} \rightarrow 2 \mathrm{CuO}(s)
\end{aligned}
$$

$\mathrm{C} 1$; photoexcited electron:

$$
2 \mathrm{CuO}(s)+2 e^{-}{ }_{\mathrm{ph}} \rightarrow \mathrm{Cu}_{2} \mathrm{O}(s)+\mathrm{O}^{2-}(\mathrm{aq})
$$

To identify the electrodeposited films, XRD analysis was carried out, as shown in Fig. 4. The three peaks appearing at $36.4^{\circ}, 42.3^{\circ}$, and $61.3^{\circ}$ were indexed, respectively, to the 111 , 200 , and 220 crystal planes of $\mathrm{Cu}_{2} \mathrm{O}$ with cubic symmetry (JCPDS 05-0667). The 61.3 ${ }^{\circ}$ peak (220) was unfortunately superimposed on the $61.7^{\circ}$ peak for FTO. $\mathrm{Cu}_{2} \mathrm{O}$ films exhibited moderately weaker peaks than the underlying FTO thin films. With increasing temperature, the full width at half maximum (FWHM) of the (111) peak decreased. At $323 \mathrm{~K}$ and $333 \mathrm{~K}, \mathrm{FWHMs}$ of the more intense peak (111) were obtained, by Lorentzian fitting, as $0.54^{\circ}$ and $0.49^{\circ}$, respectively, under the dark condition, but at $293 \mathrm{~K}, 303 \mathrm{~K}$, and $313 \mathrm{~K}$, the FWHM could not be calculated. While under illumination, FWHMs at $323 \mathrm{~K}$ and $333 \mathrm{~K}$ were simulated as $0.449^{\circ}$ and $0.45_{0}^{\circ}$, respectively, and at $293 \mathrm{~K}, 303 \mathrm{~K}$, and $313 \mathrm{~K}$ as $0.82^{\circ}, 0.56^{\circ}$, and $0.44_{7}^{\circ}$, respectively. The differ-

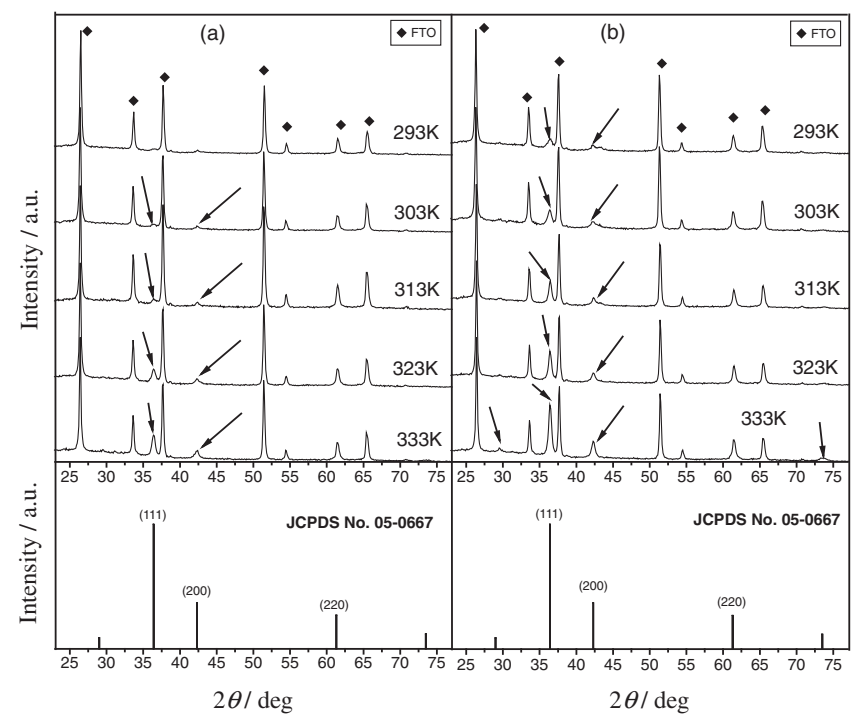

Fig. 4 XRD spectra of the electrodeposited $\mathrm{Cu}_{2} \mathrm{O}$ films, obtained in darkness (a) and with irradiation (b), under the same conditions as Fig. 2.

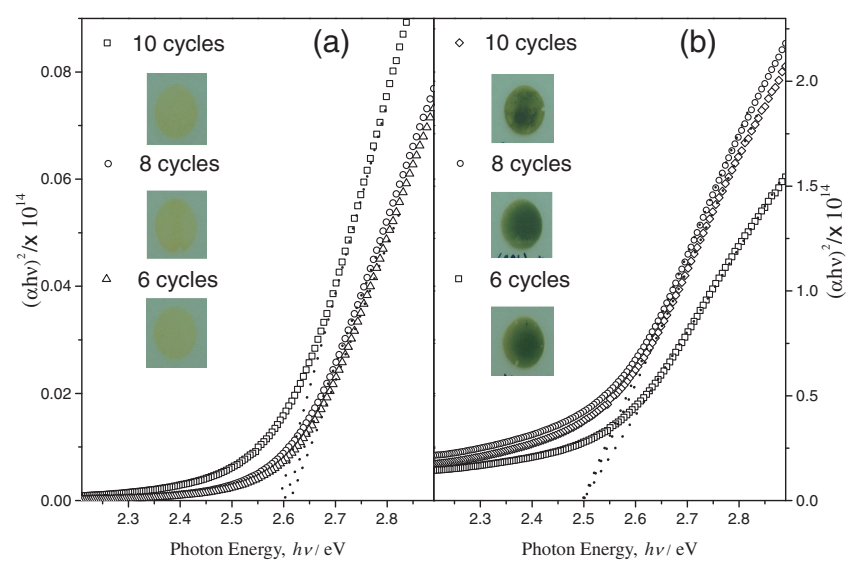

Fig. 5 Plots of $(\alpha h \nu)^{2}$ vs. photon energy for determination of the band-gap energies for $\mathrm{Cu}_{2} \mathrm{O}$ films by cyclic voltammetry, at $293 \mathrm{~K}$, for electrodeposition in darkness (a) and with irradiation (b).

ence in area and height of the (111) peak at $333 \mathrm{~K}$, between the dark and light experiments, was 2.38 times and 2.56, respectively. These values led us to assume that the $\mathrm{Cu}_{2} \mathrm{O}$ electrodeposition was effected by increasing temperature, which increases the diffusion rate of precursors in the electrolyte solution and lowers the activation energy. Furthermore, light exposure during the electrodeposition accelerates the growth of $\mathrm{Cu}_{2} \mathrm{O}$ films because the $\mathrm{Cu}_{2} \mathrm{O}$ film possesses the characteristics of a semiconductor that is responsive to the light.

Color variations after the 5 th cycle of $\mathrm{CV}$ were observed on the FTO-surface, owing to the buildup of a film with a characteristic yellow or green color, in the dark or in the light, respectively, as can be seen in the images in Fig. 5. Optical absorption studies of the $\mathrm{Cu}_{2} \mathrm{O}$ films were carried out in the wavelength range $280-1100 \mathrm{~nm}$. To estimate the band-gap energy $\left(E_{\mathrm{g}}\right)$ of the $\mathrm{Cu}_{2} \mathrm{O}$, the values of $(\alpha h \nu)^{2}$ versus $h v$ were plotted in Fig. 5. The optical band-gap was calculated using the Tauc relation: ${ }^{31)}$

$$
\alpha h v=A\left(h v-E_{\mathrm{g}}\right)^{m}
$$


(a)

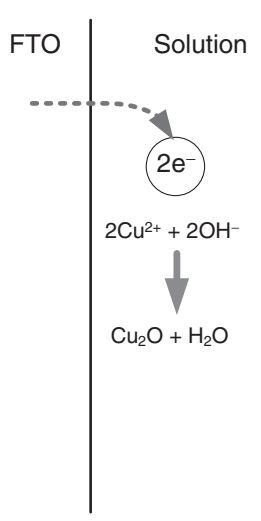

(b)

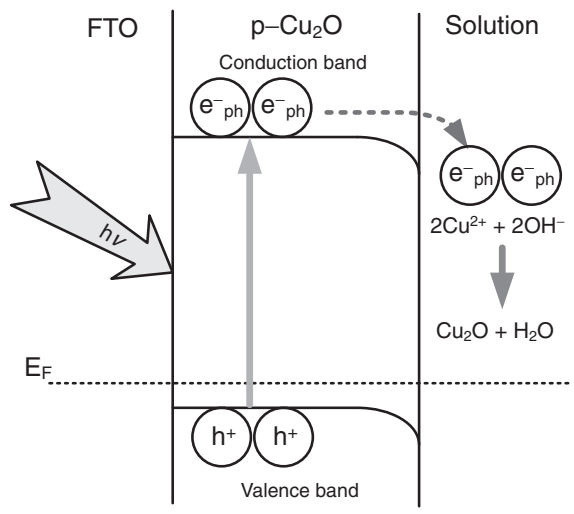

Fig. 6 Schematic electrodepositions of $\mathrm{Cu}_{2} \mathrm{O}$ for FTO $\mid$ Solution (a) and $\mathrm{FTO}\left|\mathrm{Cu}_{2} \mathrm{O}\right|$ Solution (b) systems.

$$
\alpha=\ln \frac{\left(\frac{1}{T}\right)}{d}
$$

where $A$ is a constant, $h v$ is the incident photon energy, $\alpha$ is absorption coefficient, $E_{\mathrm{g}}$ is the band-gap energy of the film, $m=2$ for the allowed direct transition, $T$ is transmittance and $d$ is the film thickness. The direct band-gap of $\mathrm{Cu}_{2} \mathrm{O}$ films electrodeposited in the dark (Fig. 5(a)) and under illumination (Fig. 5(b)) was determined by extrapolating the straight line to the energy axis and were found to be around 2.5 to $2.6 \mathrm{eV}$. These measured values of $E_{\mathrm{g}}$ were larger than typical values $(2.1 \mathrm{eV})$ accepted for polycrystalline $\mathrm{Cu}_{2} \mathrm{O}$ films suitable for hetero junction solar cells used to mate with the $\mathrm{Cu}_{2} \mathrm{O}$, such as $\mathrm{ZnO},{ }^{32)} \mathrm{TiO}_{2},{ }^{33)} \mathrm{In}_{2} \mathrm{~S}_{3},{ }^{34)}$ and $\mathrm{CdO} .{ }^{35)}$ The expansion of band-gap energy could be explained by the change of lattice parameter due to trace amounts of impurities incorporated in the electrodeposition of $\mathrm{Cu}_{2} \mathrm{O} .{ }^{36,37)}$

The photoassisted electrodeposition enhancement is schematically discussed in Fig. 6. In first cathodic sweep $\mathrm{Cu}^{2+}$ ions were reduced by electrochemical processes to $\mathrm{Cu}_{2} \mathrm{O}$ on the optically transparent conducting glass (FTO) such as in Fig. 6(a). The semiconductor $\mathrm{Cu}_{2} \mathrm{O}$ deposited on FTO was excited by absorption of photons so photoexcited electrons $\left(e^{-} \mathrm{ph}\right)$ diffused toward the interface of the solution were participated in the electrochemical deposition of $\mathrm{Cu}_{2} \mathrm{O}$ as in Fig. 6(b).

\section{Conclusion}

In this work, $\mathrm{Cu}_{2} \mathrm{O}$ films were electrochemically deposited on FTO in the dark and in the light, from an aqueous $\mathrm{CuSO}_{4}$ and lactic acid solution adjusted to $\mathrm{pH} 12$ with $\mathrm{NaOH}$. Both deposited films were identified as having cubic symmetry structured $\mathrm{Cu}_{2} \mathrm{O}$. The deposition rate was found to be higher under illumination than in the dark, at the same temperature. The driving force under illumination was considered to be a photoinduced hole produced from a valence band of the $\mathrm{Cu}_{2} \mathrm{O}$ semiconductor film. We conclude that the photoassisted electrodeposition of $\mathrm{Cu}_{2} \mathrm{O}$ could be a useful method for lowering the temperature and shortening the deposition time. Further study is taking place to examine the mechanism closely and to ascertain whether other compounds may be used.

\section{REFERENCES}

1) J. Morales, L. Sanchez, S. Bijani, L. Martinez, M. Gabas and J. R. Ramos-Barrado: Electrochem. Solid-State Lett. 8 (2005) A159-A162.

2) S. Bijani, M. Gabas, L. Martinez, J. R. Ramos-Barrado, J. Morles and L. Sanchez: Thin Solid Films 515 (2007) 5505-5511.

3) Y. Gu, X. Su, Y. Du and C. Wang: Appl. Surf. Sci. 256 (2010) 58625866.

4) G. Wu, W. Zhai, F. Sun, W. Chen, Z. Pan and W. Li: Mater. Res. Bull. 47 (2012) 4026-4030.

5) L. Xu, H. Xu, S. Wu and X. Zhang: Appl. Surf. Sci. 258 (2012) 4934 4938.

6) S. Felix, P. Kollu, B. P. C. Raghupathy, S. K. Jeong and A. N. Grace: J. Chem. Sci. 126 (2014) 25-32.

7) M. Bao, D. Wang, S. Liu, L. Kuang, J. Sun, F. Wang and Y. Wen: Appl. Surf. Sci. 258 (2012) 8008-8014.

8) Y.-H. Won and L. A. Stanciu: Sensors 12 (2012) 13019-13033.

9) Y. Qian, F. Ye, J. Xu and Z.-G. Le: Int. J. Electrochem. Sci. 7 (2012) 10063-10073.

10) S. Haller, J. Jung, J. Rousset and D. Lincot: Electrochim. Acta 82 (2012) 402-407.

11) Y. Mao, J. He, X. Sun, W. Li, X. Lu, J. Gan, Z. Liu, L. Gong, J. Chen, P. Liu and Y. Tong: Electrochim. Acta 62 (2012) 1-7.

12) J. Y. Zheng, A. P. Jadhav, G. Song, C. W. Kim and Y. S. Kang: Thin Solid Films 524 (2012) 50-56.

13) B. M. Fariza, J. Sasano, T. Shinagawa, S. Watase and M. Izaki: Thin Solid Films 520 (2012) 2261-2264.

14) Y. Kim, J. Jung, S. Kim and W.-S. Chae: Mater. Trans. 54 (2013) 14671472 .

15) F. Sun, Y. Guo, W. Song, J. Zhao, L. Tanf and Z. Wang: J. Cryst. Growth 304 (2007) 425-429.

16) T. Mahalingam, J. S. P. Chitra, J. P. Chu and P. J. Sebastian: Mater. Lett. 58 (2004) 1802-1807.

17) F. Sun, Y. Gao, Y. Tian, J. Zhang, X. Lv, M. Li, Y. Zheng and Z. Wang: J. Cryst. Growth 310 (2008) 318-323.

18) G. Riveros, A. Garmendia, D. Ramirez, M. Tejos, P. Grez, H. Gomez and E. A. Dalchiele: J. Electrochem. Soc. 160 (2013) D28-D33.

19) M.-C. Hung, T. Wang, W.-S. Chang, J.-C. Lin, C.-C. Wu, I.-C. Chen, K.-C. Peng and S.-W. Lee: Appl. Surf. Sci. 301 (2014) 369-377.

20) M. Izaki, S. Sasaki, F. B. Mohamad, T. Shinagawa, T. Ohta, S. Watase and J. Sasano: Thin Solid Films 520 (2012) 1779-1783.

21) Y. S. Jeong, H. Kim and H. S. Lee: J. Alloy. Compd. 573 (2013) 163169.

22) T. Fujiwara, T. Nakaue and M. Yoshimura: Solid State Ionics 175 (2004) 541-544

23) X. Han, K. Han and M. Tao: Thin Solid Films 518 (2010) 5363-5367.

24) D. K. Zhong, M. Cornuz, K. Sivula, M. Gratzel and D. R. Gamelin: Energy Environ. Sci. 4 (2011) 1759-1764.

25) K. Kamada, K. Higashikawa, M. Inada, N. Enomoto and J. Hojo: J. Phys. Chem. C 111 (2007) 14508-14513.

26) M. Izaki, K. Mizuno, T. Shinagawa, M. Inaba and A. Tasaka: J. Electrochem. Soc. 153 (2006) C668-C672.

27) J. Zang, M. An and L. Chang: Electrochim. Acta 54 (2009) 2883.

28) A. I. Inamdar, S. H. Mujawar and P. S. Patil: Int. J. Electrochem. Soc. 2 (2007) 797.

29) S. Bugarinovic, M. Rajcic-Vujasinovic, Z. Stevic and V. Grekulovic: Solar Cells - New Aspects and Solutions, ed. by L. A. Kosyachenko, (InTech, 2011) p. 174.

30) J. O’M. Bockris and S. U. M. Khan: Surface Electrochemistry, (Plenum Press, New York, 1993) pp. 319-349.

31) J. Tauc: Amorphous and Liquid Semiconductors, (Plenum Press, New York, 1974) pp. 159-220.

32) J.-W. Chen, D.-C. Perng and J.-F. Fang: Sol. Energy Mater. Sol. Cells 95 (2011) 2471-2477.

33) M. Santamaria, G. Conigliaro, F. D. Franco and F. D. Quarto: Electrochim. Acta 144 (2014) 315-323.

34) R. Jayakrishnan: Mater. Sci. Semicond. Process. 16 (2013) 1608-1612.

35) Y. Hameș and S. E. San: Sol. Energy 77 (2004) 291-294.

36) T. Pauporte and D. Lincot: Appl. Phys. Lett. 75 (1999) 3817-3819.

37) T. Shinagawa, M. Izaki, H. Inui, K. Murase and Y. Awakura: J. Electrochem. Soc. 152 (2005) G736-G741. 